\title{
A modelling approach to quantify the influence of fine sediment deposition on biogeochemical processes occurring in the hyporheic zone
}

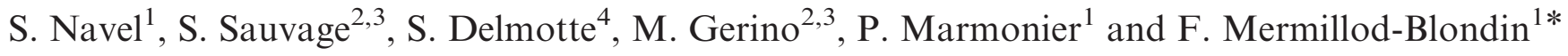 \\ ${ }^{1}$ Université de Lyon, UMR5023 Ecologie des Hydrosystèmes Naturels et Anthropisés, Université Lyon 1, ENTPE, CNRS, \\ 6 rue Raphaël Dubois, 69622 Villeurbanne, France \\ 2 CNRS, UMR 5245, EcoLab, 31326 Castanet Tolosan, France \\ ${ }^{3}$ Université de Toulouse, INP, UPS, EcoLab (Laboratoire Ecologie Fonctionnelle et Environnement), ENSAT, \\ avenue de l'Agrobiopole, 31326 Castanet Tolosan, France \\ 4 MAD-Environnement, Allée des Demoiselles, 33170 Gradignan, France
}

Received 14 November 2011; Accepted 1 May 2012

\begin{abstract}
Excessive sedimentation of fine particles on stream beds has been recognized as a major threat to running-water ecosystems. Deposition of fine sediments often affects hyporheic zone (HZ) functioning by (1) reducing hydrological exchanges at the water-sediment interface and by (2) increasing the organic matter $(\mathrm{OM})$ content of surface sediments. These two factors usually occur concurrently to control biogeochemical processes in sediments. In the present study, experimental and modelling approaches were coupled to evaluate the contribution of these factors on the biogeochemical functioning of the HZ. We used a one-dimensional (1D) vertical model taking into account the hydrodynamic properties, the vertical distribution of the OM and the main microbial processes involved in OM processing (aerobic respiration, denitrification, nitrification and sulphate reduction). This Mobile-Immobile Model for Organic Matter (MIM-OM) model was calibrated and validated using experimental data (conservative tracer, dissolved oxygen and nitrate concentrations) obtained in filtration columns filled with a porous sedimentary matrix. Simulations showed that organic carbon content and Darcy velocity acted in concert to shape biogeochemical processes in stream sediments. The use of the MIM-OM model on data obtained in filtration columns impacted by fine sediment deposition indicated that the biodegradability of the OM (modified through the degradation parameter $k_{\mathrm{POC}}$ ) also played a key role on biogeochemical processes occurring in sediments. In conclusion, the MIM-OM model appears as an efficient simulation tool to evaluate biogeochemical functioning in river sediments under different conditions (granulometry, quality of surface water and clogging).
\end{abstract}

Key words: Mathematical modeling / hyporheic zone / organic carbon / clogging / biogeochemistry

\section{Introduction}

The clogging of streambed sediments, defined as the deposition, accumulation and infiltration of fine sediments, is a major environmental concern throughout the world (Waters, 1995; Wood and Armitage, 1997) affecting habitats and biogeochemical functioning in running waters. Human activities, including mining, dam construction, agriculture and urbanization (Hancock, 2002) increase the deposition of fine particles in streams and rivers and therefore lead to the physical clogging of stream beds (Schälchli, 1992). By reducing permeability and porosity

\footnotetext{
*Corresponding author: mermillo@univ-lyon1.fr
}

(Beschta and Jackson, 1979; Gayraud and Philippe, 2003), clogging may greatly alter dissolved oxygen $\left(\mathrm{O}_{2}\right)$ supply and dynamics within the hyporheic zone (HZ). Boulton et al. (1998) predicted that sediment clogging because of fine particle deposition could induce intense bacterial activity in surface sediments, lowering $\mathrm{O}_{2}$ availability in the $\mathrm{HZ}$ and thereby decreasing aerobic microbial processes (aerobic respiration and nitrification) in favour of anaerobic processes such as denitrification, fermentation and methanogenesis (Lefebvre et al., 2004; Nogaro et al., 2007). However, Nogaro et al. (2010) reported that sediment deposition did not produce comparable effects on biogeochemical processes in $\mathrm{HZ}$ of three French rivers because of differences in (i) the degree of sediment clogging 


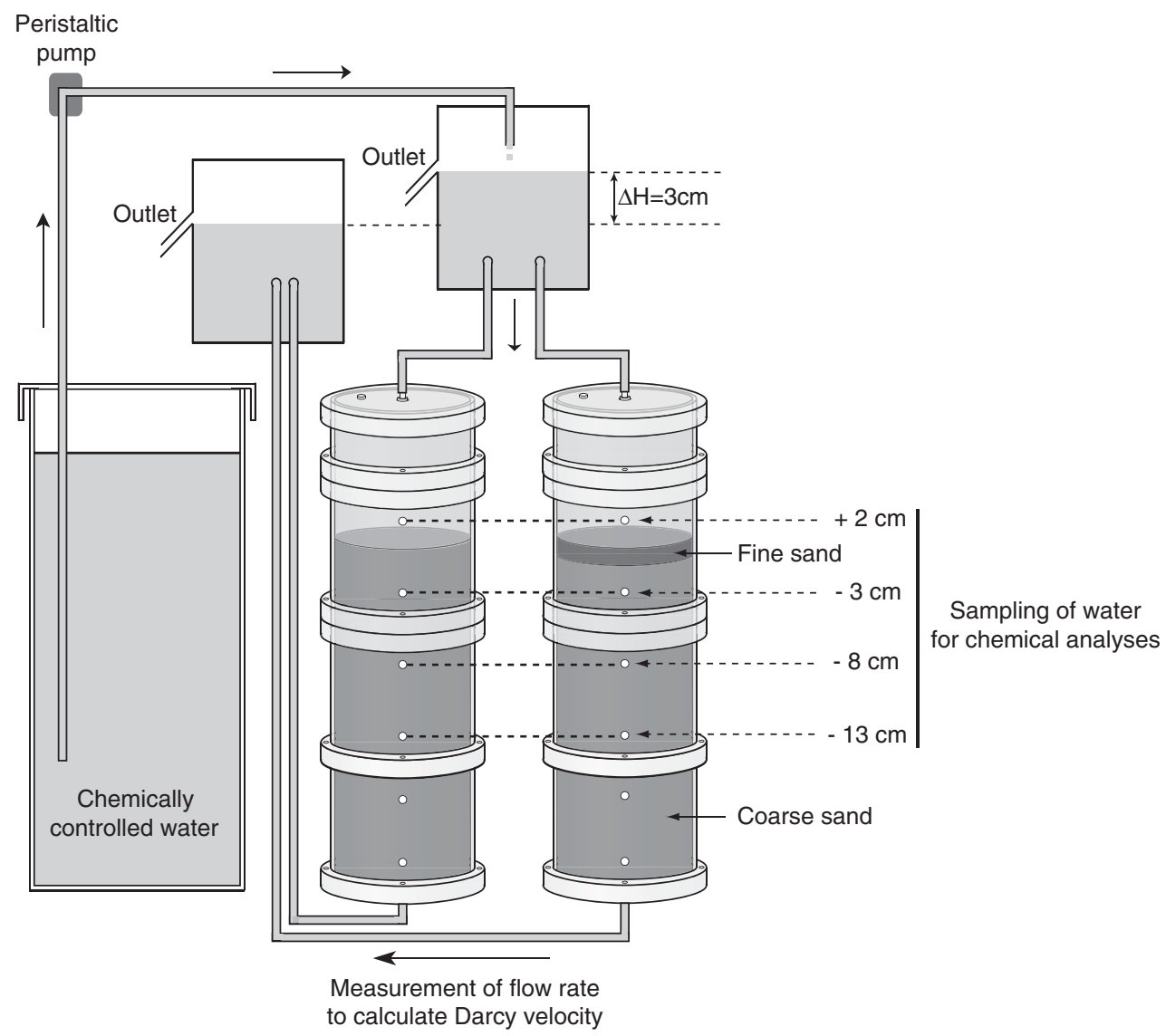

Fig. 1. Schematic representation of the experimental device: example with two filtration columns filled with coarse sand and topped by a layer of coarse or fine sand (non-impacted and impacted treatments, respectively).

and (ii) the organic matter (OM) characteristic of the deposited sediments. To assess the relative contributions of these two factors on the HZ functioning, research needs to fully integrate the mechanisms linking physico-chemical characteristics in the HZ (hydrodynamics, electron acceptor availability and OM content) with microbial processes. The present study aimed to achieve this goal by (i) applying a mathematical model on data obtained in sedimentary systems impacted or not by fine sediment deposition at the laboratory and (ii) simulating the effect of parameters related to fine sediment deposition (i.e., modifications of Darcy velocity and OM content at the sediment surface) on biogeochemical profiles in the HZ.

\section{Materials and methods}

\section{Laboratory experiment}

\section{Experimental design}

Experiments were undertaken in eight filtration columns (35-cm height, 10-cm diameter, Fig. 1) filled with gravels $(2-4 \mathrm{~mm})$ and sand $(0.1-1 \mathrm{~mm})$ collected from the Rhône River and previously elutriated and cleaned with deionized water to eliminate coarse particulate OM (see details for column preparation in Navel et al., 2011). This sedimentary matrix (thickness: $25 \mathrm{~cm}$ ) was topped by an additive 2 -cm-thick layer of coarse sand $(90 \%$ of particles $>0.29 \mathrm{~mm})$ or fine sand $(90 \%$ of particles $<0.16 \mathrm{~mm})$ to simulate non-impacted systems and systems impacted by fine sediment deposition ( $n=4$ columns per condition), respectively. The total organic carbon (TOC), total nitrogen (TN) and total phosphorous (TP) contents reported per dry mass of sediment strongly differed between coarse and fine sand: 0.97 versus $16.6 \mathrm{~g}$ of TOC. $\mathrm{kg}^{-1}, 0.17$ versus $1.35 \mathrm{~g}$ of TN. $\mathrm{kg}^{-1}$, and 3.76 versus $6.62 \mathrm{mg}$ of TP. $\mathrm{kg}^{-1}$ of coarse and fine sand, respectively. After the addition of sediment, all columns were filled to the top with chemically controlled water $\left(96 \mathrm{mg} . \mathrm{L}^{-1} \mathrm{NaHCO}_{3}, 39.4 \mathrm{mg} . \mathrm{L}^{-1}\right.$ $\mathrm{CaSO}_{4} \cdot 2 \mathrm{H}_{2} \mathrm{O}, 60 \mathrm{mg} . \mathrm{L}^{-1} \mathrm{MgSO}_{4} \cdot 7 \mathrm{H}_{2} \mathrm{O}, 4 \mathrm{mg} . \mathrm{L}^{-1} \mathrm{KCl}$, $19 \mathrm{mg} . \mathrm{L}^{-1} \mathrm{Ca}\left(\mathrm{NO}_{3}\right)_{2} \cdot 4 \mathrm{H}_{2} \mathrm{O}$ and $1.6{\mathrm{mg} . \mathrm{L}^{-1}}^{-1}$ $\left(\mathrm{CH}_{3} \mathrm{CO}_{2}\right)_{2} \mathrm{CaH}_{2} \mathrm{O}$ in deionized water; $\mathrm{pH}=7.5$; US EPA, 1991) saturated with $\mathrm{O}_{2}$ by an air pump, under constant hydraulic pressure $(\triangle H=3 \mathrm{~cm})$. About $10 \mathrm{~cm}$ of free water depth was maintained above the sediment surface and was exposed to a $12 \mathrm{~h}$ light/12 h dark cycle, whereas the sedimentary column was kept in the dark (using black adhesive tape) to suppress photoautotrophic processes. The experiment was performed at a constant temperature of $15 \pm 0.5^{\circ} \mathrm{C}$. 


\section{Analyses}

To characterize the water transport in sediments impacted or non-impacted by fine sediment deposition, tracer experiments were realized according to the method described by Mermillod-Blondin et al. (2004). At the end of the experiment (10 days after column settlement), we measured Darcy velocity and collected water samples (20 $\mathrm{mL})$ at four depths $(+2 \mathrm{~cm}$ above, $-3,-8$ and $-13 \mathrm{~cm}$ below the water-sediment interface) in all columns to determine the impact of sediment deposition on hydraulic transfer and vertical profiles of $\mathrm{O}_{2}$ and $\mathrm{NO}_{3}^{-}$concentrations. Oxygen concentrations were determined using an oxygen micro-sensor probe fitted in a glass tube (OX 500, Unisense, Aarhus, Denmark) during water sample collection, allowing measurements without contact with atmospheric oxygen (for details, see Navel et al., 2011)., $\mathrm{NO}_{3}^{-}$ concentrations were measured following a standard colorimetric method after filtration through Whatman GF/F filters (pore size: $0.7 \mu \mathrm{m}$; Millipore, Billerica, MA, U.S.A.) by using an automatic analyser (Easychem Plus, Systea, Anagni, Italia). We were particularly interested in $\mathrm{O}_{2}$ and $\mathrm{NO}_{3}^{-}$profiles in the present study as they are representative of the main biogeochemical processes (aerobic respiration and denitrification) occurring in sediment columns (Mermillod-Blondin et al., 2005; Nogaro et al., 2007; Navel et al., 2011). The impact of sediment deposition on the vertical profiles of $\mathrm{O}_{2}$ and $\mathrm{NO}_{3}^{-}$concentrations was statistically tested using a two-way ANOVA with depth and sediment treatment ("impacted" versus "non-impacted" by fine sediment deposition) as main effects. Statistical analyses were performed using Statistica 5TM (Statsoft).

\section{The modelling approach}

The model presented in this study (MIM-OM) is based on transport-reactive processes occurring in a macroporous matrix with a water volume split into a mobile fraction and an immobile fraction. It corresponds to the Mobile-Immobile-Model (MIM model, Gaudet et al., 1977; Schoen et al., 1999; Mermillod-Blondin et al., 2004), which is commonly used for modelling conservative water transport. This type of model permits a simulation of advective-dispersive transport of a dissolved solute in a porous media composed of a mobile phase (zone of the sedimentary column where the water flows) and an immobile phase (zone highly colonized by heterotrophic biofilms and where water does not flow). The solute is transported into the sediments within the mobile phase and is processed within the sediment in the immobile phase. Exchanges between the two phases are realized according to an exchange coefficient. Such an approach with two water phases is efficient to simulate anaerobic processes occurring in sediments where average $\mathrm{O}_{2}$ conditions are aerobic. For instance, Peyrard et al. (2011) showed that the anaerobic degradation of particulate organic carbon (POC) could occur in the immobile zone of hyporheic sediments even if $\mathrm{O}_{2}$ concentrations were high in the mobile phase.

The transport-reactive model (MIM-OM) consisted of the incorporation of reactive processes in the transport model by addition of biogeochemical reactions (aerobic respiration, denitrification, nitrification and sulphate reduction) involved in the degradation of particulate and dissolved OM (Table 1). Therefore, the model integrates the following components: $\left[\mathrm{O}_{2}\right],\left[\mathrm{NO}_{3}^{-}\right],\left[\mathrm{NH}_{4}^{+}\right]$and $\left[\mathrm{SO}_{4}^{2-}\right]$. The resulting MIM-OM model is described by two equations:

$$
\begin{gathered}
\frac{\partial C_{\gamma}^{t}}{\partial t}+\frac{v}{\partial x}-\frac{\partial C_{\gamma}^{t}}{\partial x}-D_{\gamma}^{i} \frac{\partial^{2} C_{\gamma}^{t}}{\partial x^{2}}=-\frac{\alpha}{\varepsilon_{\gamma}}\left(C_{\gamma}^{i}-C_{\omega}^{i}\right)+R_{\gamma}^{i} \\
\frac{\partial C_{\omega}^{t}}{\partial t}=\frac{\alpha}{\left(\varepsilon-\varepsilon_{\gamma}\right)}\left(C_{\gamma}^{i}-C_{\omega}^{i}\right)+R_{\omega}^{i}
\end{gathered}
$$

where $C^{i}{ }_{\gamma}$ is the solute concentration $i$ in the mobile phase ( $\mu$ mol. $\mathrm{L}^{-1}$ ), $t$ is the time $(\mathrm{h}), x$ is the distance (column depth) (cm), $C_{\omega}^{i}$ is the solute concentration $i$ in the immobile phase (biofilm) $\left(\mu \mathrm{mol} . \mathrm{L}^{-1}\right), v$ is the Darcy velocity (advection) $\left(\mathrm{cm}^{-\mathrm{h}^{-1}}\right), D_{\gamma}^{i}$ is the dispersion coefficient of the solute $i\left(\mathrm{~cm}^{2} \cdot \mathrm{h}^{-1}\right), \alpha$ is the exchange coefficient between mobile and immobile phase $\left(\mathrm{h}^{-1}\right), \varepsilon_{\gamma}$ is the volumetric fraction of the mobile phase, $\varepsilon$ is the total porosity, $R_{\gamma}^{i}$ and $R_{\omega}^{i}$ are reaction terms for the solute $i$, respectively, in mobile phase and immobile phase $\left(\mu \mathrm{mol} . \mathrm{L}^{-1} \cdot \mathrm{h}^{-1}\right)$.

We considered the solid matrix containing the POC to be immobile and used a third equation for the modelling of POC degradation:

$$
\frac{\partial[\mathrm{POC}]}{\partial t}=-R_{\mathrm{POC}}
$$

with $R_{\mathrm{POC}}$ as a reaction term for this component. The four biogeochemical reactions introduced in the model are: (i) aerobic respiration, (ii) denitrification, (iii) sulphate reduction and (iv) nitrification.

For particulate and dissolved OM, global degradation rates $\left(k_{\mathrm{POC}}\right.$ and $\left.k_{\mathrm{DOC}}\right)$ were used. The relative contribution of each metabolic route in this global degradation rate is simulated according to the availability of each oxidant. To represent the metabolic successive reactions along an aerobic-anaerobic gradient, limitation and inhibition functions for metabolic routes are used: $\mathrm{O}_{2}$ concentrations activate aerobic degradation and inhibit denitrification and sulphate reduction functions; denitrification is activated when concentrations in $\mathrm{O}_{2}$ are limiting and $\mathrm{NO}_{3}^{-}$is available and inhibit the sulphate reduction process in the porous media. These functions are described in Table 1 with the biogeochemical parameters presented in Table 2. For this case study, we assumed that the processes were located in the heterotrophic biofilms and, then, the reactions were only activated in the immobile phase. Exchange coefficient and immobile phase volume controlled the differences in solute concentrations between the immobile and mobile phases. The concentrations in the mobile phase (solutes and OM) were the results of all the bio-physical processes acting in the sediment. 
Table 1. Functions used in the model linking OM decomposition rates and biogeochemical reactions.

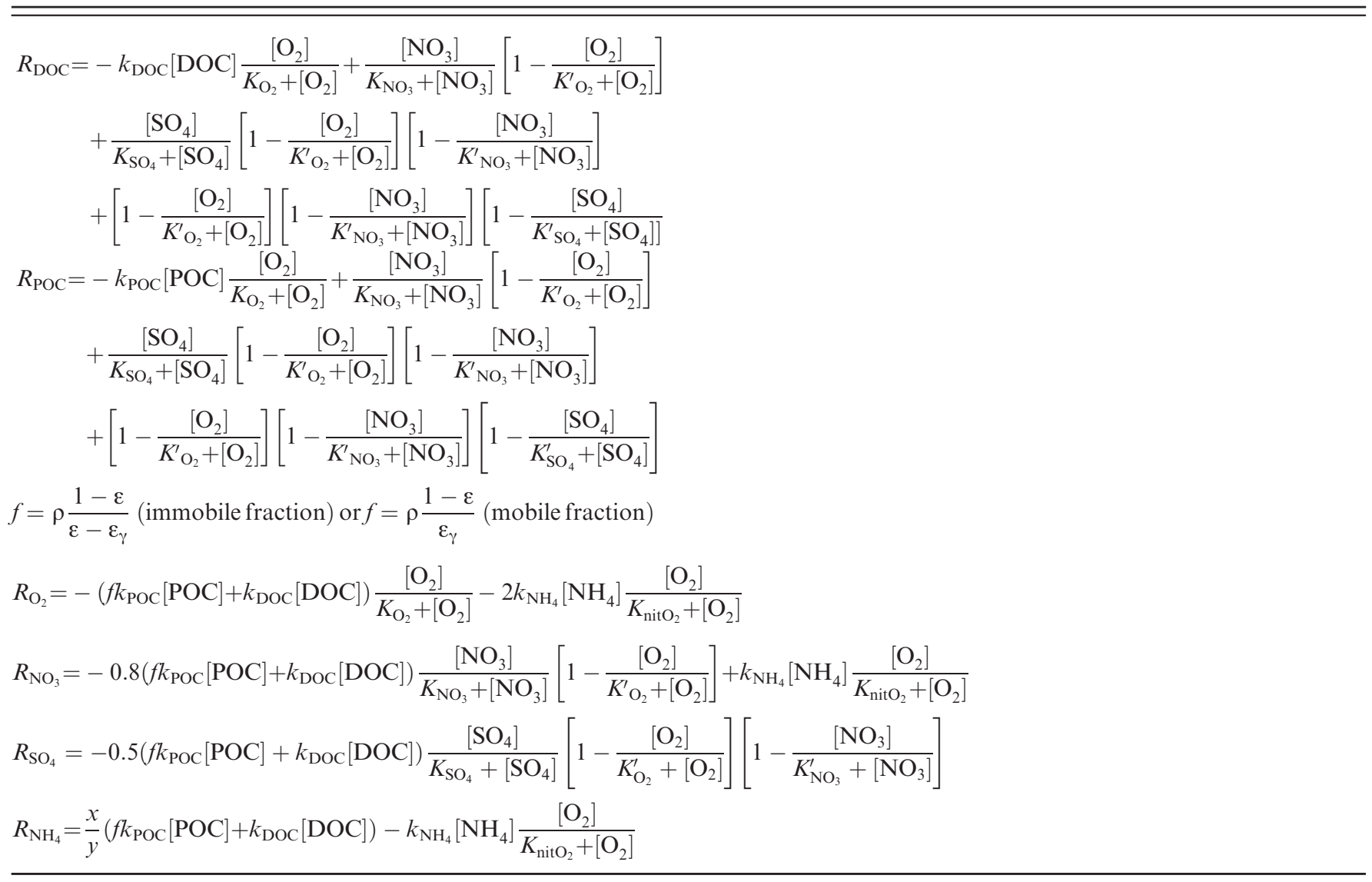

Table 2. Physical and biogeochemical parameters used in the model for the simulation of $\mathrm{O}_{2}$ and $\mathrm{NO}_{3}^{-}$profiles in slow filtration columns.

\begin{tabular}{|c|c|c|}
\hline Parameters & Values & Description \\
\hline \multicolumn{3}{|l|}{ Physical parameters } \\
\hline Diffusion $D_{\gamma}^{i}$ of the solute $i\left(\mathrm{~cm}^{2} \cdot \mathrm{h}^{-1}\right)$ & 4.5 & M \\
\hline Darcy velocity $\left(\mathrm{cm} \cdot \mathrm{h}^{-1}\right)$ with a top layer of coarse sand & 2.29 & M \\
\hline Darcy velocity $\left(\mathrm{cm} \cdot \mathrm{h}^{-1}\right)$ with a top layer of fine sand & 0.38 & M \\
\hline Exchange coefficient $\alpha$ between mobile and immobile phases $\left(\mathrm{h}^{-1}\right)$ & 1.4 & M \\
\hline Porosity $\varepsilon$ & 0.33 & M \\
\hline Volume fraction of mobile phase $\varepsilon_{\gamma}$ & 0.28 & M \\
\hline Dry sediment density $\rho\left(\mathrm{g} \cdot \mathrm{cm}^{-3}\right)$ & 2.65 & M \\
\hline \multicolumn{3}{|l|}{ Biogeochemical parameters } \\
\hline Molar C:N:P ratio $(x: y: z)$ for OM (POC and DOC) & $262: 46: 1$ & $\mathrm{M}$ \\
\hline DOC degradation rate $k_{\mathrm{DOC}}\left(\mathrm{h}^{-1}\right)$ & 3 & $\mathrm{O}$ \\
\hline POC degradation rate $k_{\mathrm{POC}}\left(\mathrm{h}^{-1}\right)$ with a top layer of coarse sand & $3 \times 10^{-5}$ & $\mathrm{O}$ \\
\hline POC degradation rate $k_{\mathrm{POC}}\left(\mathrm{h}^{-1}\right)$ with a top layer of fine sand & $1 \times 10^{-4}$ & $\mathrm{O}$ \\
\hline Nitrification rate $k_{\mathrm{NH}_{4}}\left(\mathrm{~h}^{-1}\right)$ & 1 & Van Cappellen and Wang (1996) \\
\hline Half-saturation constant for oxygen limitation in $\mathrm{OM}$ degradation $K_{\mathrm{O}_{2}}(\mu \mathrm{M})$ & 3.1 & Van Cappellen and Wang (1996) \\
\hline Half-saturation constant for oxygen limitation in nitrification $K_{\mathrm{nit}_{2}}(\mu \mathrm{M})$ & 10 & Van Cappellen and Wang (1996) \\
\hline Inhibition constant for oxygen $K_{\mathrm{O}_{2}}^{\prime}(\mu \mathrm{M})$ & 10 & Van Cappellen and Wang (1996) \\
\hline Half-saturation constant for nitrate limitation $K_{\mathrm{NO}_{3}}(\mu \mathrm{M})$ & 30 & Van Cappellen and Wang (1996) \\
\hline Inhibition constant for nitrate $K_{\mathrm{NO}_{3}}^{\prime}(\mu \mathrm{M})$ & 10 & Van Cappellen and Wang (1996) \\
\hline Half-saturation constant for sulphate limitation $K_{\mathrm{SO}_{4}}(\mu \mathrm{M})$ & 500 & Van Cappellen and Wang (1996) \\
\hline Inhibition constant for sulphate $K_{\mathrm{SO}_{4}}^{\prime}(\mu \mathrm{M})$ & 500 & Van Cappellen and Wang (1996) \\
\hline Vertical POC profile $(\%)$ & 0.1 & M \\
\hline POC in the upper layer for coarse sand $(\%)$ & 0.1 & M \\
\hline POC in the upper layer for fine sand $(\%)$ & 1 & M \\
\hline
\end{tabular}

$\mathrm{M}$, measured parameters during experiments; $\mathrm{O}$, parameter derived by model simulation. 


\section{Numerical solution}

The reactive model equations were approximated following a finite difference scheme. To ensure that the differencing scheme was second-order accurate and stable, a blend of backward (advection dominated) and central differences (diffusion dominated) is used (Fiadeiro and Veronis, 1977). The resulting derivatives of model equations were solved using the method of lines (MOL). It is one of the most powerful solution method to solve timedependent partial differential equations (PDEs) (Ramos, 1986): a single time and space-dependent PDE becomes a set of time-dependent ordinary differential equations (ODEs), valid at each grid point, when spatial finite differences are substituted for spatial derivatives in the original equation. The system has been solved in Fortran 90 by using the ODEs solver DVODE (https://computation. 1lnl.gov/casc/software.html) for stiff ODE. The compiled source codes for the two models can be used by a user graphic interface developed with Smalltalk VisualWorks (http://www.cincomsmalltalk.com/main/products/visual works/).

\section{Calibration and validation on experimental data}

In the present study, all simulated and measured solute concentrations belong to the mobile phase ( $\gamma$ phase). Physical parameters of water transport (i.e., dispersion coefficient of the solute, exchange coefficient between mobile and immobile phase and volumetric fraction of the mobile phase) were calculated from the transport of a conservative tracer (equations 1 and 2 with $R \omega$ and $R \gamma$ equal to zero) by inverse modelling. Using Darcy velocity and total porosity (as fixed input parameters), and transport parameters (as output parameters to fit: dispersion, porosity, volume fraction of mobile phase and exchange coefficient), the model generated simulated data (curve of tracer concentrations recovered at the outflow of columns during the time after tracer injection at the top of the columns). We selected the most representative group of physical transport parameters for each experiment (with and without clogging) that offered the best fit between the modelled and measured data obtained from the tracer experiment. The best fit was determined by minimizing the sum of squared differences between measured and modelled concentrations of conservative tracer.

After the determination of the physical transport parameters, measured dry density of sediment, molecular $\mathrm{C}: \mathrm{N}: \mathrm{P}$ ratios of $\mathrm{OM}$, percentage and vertical distribution of POC in sediments were introduced into the model (Table 2). The parameters of limitation and saturation of biogeochemical reactions were derived from the literature (Table 2). The degradation parameters $k_{\mathrm{DOC}}$ and $k_{\mathrm{POC}}$ are crucial parameters for biogeochemical processes (Decaux, 2011), but they can be highly variables depending on the composition and origin of OM (e.g., Middelburg et al., 1993). Therefore, we determined the value of $k_{\mathrm{POC}}$ in the range of data obtained from the literature by fitting measurements on the $\mathrm{O}_{2}$ and $\mathrm{NO}_{3}^{-}$profiles measured after
10 days for the non-impacted condition (with a surface layer of coarse sand). The selected value $\left(3 \times 10^{-5} \mathrm{~h}^{-1}\right.$, Table 2) was in accordance with previous works (Van Cappellen and Wang, 2006; Wijsman et al., 2002; Canavan et al., 2006; Delmotte, 2007), supporting the validity of our parameterization. For the degradation of DOC, we used a $k_{\mathrm{DOC}}$ of $3 \mathrm{~h}^{-1}$ which was higher than data commonly encountered in natural systems (Peyrard et al., 2011), because the source of DOC used in our system (acetate) was very easily consumed and metabolized by microorganisms in comparison with natural and more refractory DOC (Servais et al., 1989; Foulquier et al., 2011).

\section{Sensitivity analysis: model response to Darcy velocity and POC content changes}

To simulate the impact of sediment deposition on biogeochemical processes and then vertical profiles of $\mathrm{O}_{2}$ and $\mathrm{NO}_{3}^{-}$concentrations, simulations were performed under contrasted conditions of Darcy velocity and POC content in the surface layer of sediment, the two main parameters associated with the biogeochemical impact of the fine sediment deposition. $\mathrm{O}_{2}$ and $\mathrm{NO}_{3}^{-}$vertical profiles were simulated using five Darcy velocities $(0.25,0.5,1.0$, 2.0 and $\left.3.0 \mathrm{~cm} \cdot \mathrm{h}^{-1}\right)$ and three OM contents $(0.1,1$ and $10 \%$ of POC per mass of dry sediments) without modifying the parameters used previously in model validation.

\section{Simulations for a system impacted by fine sediment deposition}

Using the parameters (Darcy velocity and vertical profile of POC) measured during the experiment, we aimed to simulate the vertical profiles of $\mathrm{O}_{2}$ and $\mathrm{NO}_{3}^{-}$ concentrations obtained in columns impacted by fine sand deposition. Previous studies performed in slow filtration columns with several sedimentary matrices (Nogaro et al., 2007; Navel et al., 2011) showed that the biodegradability of the OM could be highly varied with its composition. We expected the same variability in biodegradability between the coarse and fine sands used in the present experiment. Therefore, simulations were made by testing several values of POC degradation rate $\left(k_{\mathrm{POC}}\right)$ ranging between $10^{-5}$ and $10^{-3} \mathrm{~h}^{-1}$. The best fit between modelled and experimental data was determined by minimizing the sum of squared differences between observed and calculated concentrations of $\mathrm{O}_{2}$ and nitrate.

\section{Results}

\section{Laboratory experiment}

Fine sediment deposition had a very significant impact on Darcy velocity and on vertical profiles of $\mathrm{O}_{2}$ and $\mathrm{NO}_{3}^{-}$ concentrations (Fig. 2, two-way ANOVA, "sediment $\times$ depth" interaction, $P<0.001$ for the two variables). Darcy velocity was reduced from 2.29 to $0.38 \mathrm{~cm} . \mathrm{h}^{-1}$ with the addition of fine sediment (Table 2). In columns not 


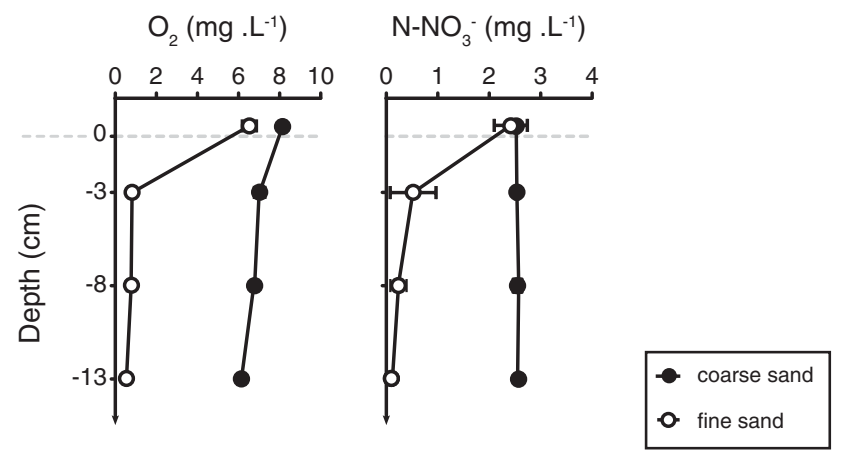

Fig. 2. Vertical profiles of $\mathrm{O}_{2}$ and $\mathrm{N}-\mathrm{NO}_{3}^{-}$measured in columns with a top layer of coarse sand (non-impacted treatment) and a top layer of fine sand (impacted treatment).

impacted by fine sediment deposition, $\mathrm{O}_{2}$ and $\mathrm{N}-\mathrm{NO}_{3}^{-}$ concentrations measured in interstitial water remained higher than 6 and $2.5 \mathrm{mg} . \mathrm{L}^{-1}$, respectively (Fig. 2). In contrast, the addition of a layer of fine sediment produced a sharp decrease in $\mathrm{O}_{2}$ and $\mathrm{NO}_{3}^{-}$concentrations in the sediment.

\section{Modelling}

Using the values of parameters reported in Table 2, the modelled $\mathrm{O}_{2}$ and $\mathrm{NO}_{3}^{-}$vertical profiles fitted well with experimental data in columns not impacted by sediment deposition (Fig. 3). To investigate how fine sediment deposition affects biogeochemistry in the HZ, the quantity of POC supplied with the layer of surface sediment and Darcy velocity in sediments were modified to simulate profiles of $\mathrm{O}_{2}$ and $\mathrm{NO}_{3}^{-}$concentrations in interstitial water (Fig. 4). The chosen ranges from 0.25 to $3 \mathrm{~cm} \cdot \mathrm{h}^{-1}$ for Darcy velocity and from 0.1 to $10 \%$ of POC in the sediment deposit layer. This analysis showed that hydraulic velocity and POC content acted in concert to shape the distributions of $\mathrm{O}_{2}$ and $\mathrm{NO}_{3}^{-}$concentrations in interstitial water. A simple reduction of Darcy velocity from 3 to $0.25 \mathrm{~cm} \cdot \mathrm{h}^{-1}$ reduced the supply of $\mathrm{O}_{2}$ in sediments, but such $\mathrm{O}_{2}$ reduction was not enough to produce a consumption of nitrate in the top $8 \mathrm{~cm}$ of the columns when organic carbon content was $10^{-3}$ (value for coarse sediments, Fig. 4(a)-(e)). The simulation analysis showed that an increased quantity of POC in the top sediment layer (from 0.1 to $10 \%)$ for low Darcy velocities $\left(0.25\right.$ and $\left.0.5 \mathrm{~cm} \mathrm{~h}^{-1}\right)$ would lead to anaerobic conditions in interstitial water by stimulating the aerobic respiration in the top sediment layer (Fig. 4(d), (e), (i), (j), (n) and (o) for $\mathrm{O}_{2}$ ). Consequently, such organic enrichment was expected to facilitate anaerobic processes and nitrate consumption by denitrification in the uppermost sediment layer (Fig. 4(d), (e), (i), (j), (n) and (o) for $\mathrm{NO}_{3}^{-}$).

In systems impacted by fine sediment deposition, the best fit between simulated and experimental data was obtained with measured data of Darcy velocity $\left(0.38 \mathrm{~cm} \cdot \mathrm{h}^{-1}\right)$, measured POC content in deposited

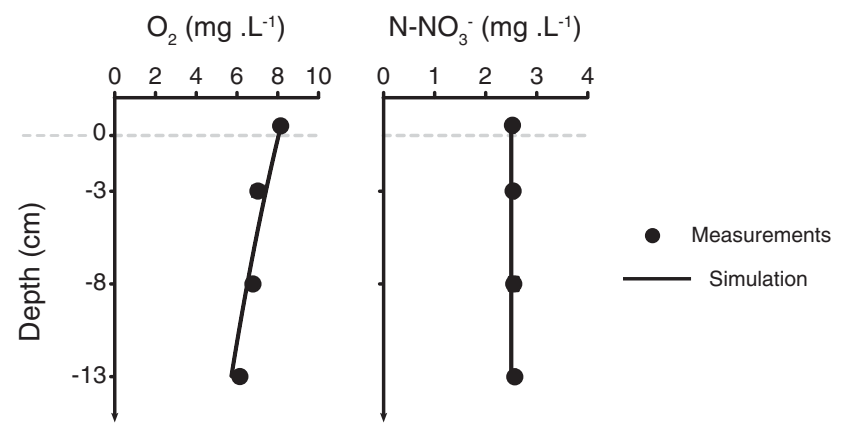

Fig. 3. Measured and simulated vertical profiles of $\mathrm{O}_{2}$ and $\mathrm{N}-$ $\mathrm{NO}_{3}^{-}$obtained in columns with a top layer of coarse sand (nonimpacted treatment).

sediment $(1.7 \%)$ and a $k_{\text {POC }}$ value of $1 \times 10^{-4} \mathrm{~h}^{-1}$ (Fig. 5). The POC degradation rate had a clear influence on vertical profiles of $\mathrm{O}_{2}$ and $\mathrm{NO}_{3}^{-}$(Fig. 5). For comparison, the value of $k_{\text {POC }}$ used in systems impacted by fine sediment deposition was 3-fold higher than the value used in systems without fine sediment (Table 2),

\section{Discussion}

Our modelling approach allowed us to simulate contrasting vertical profiles of $\mathrm{O}_{2}$ and $\mathrm{NO}_{3}^{-}$concentrations by coupling physico-chemical (hydrodynamics, DOC content, POC content and nitrate concentrations) and microbial processes (aerobic respiration and denitrification). The model efficiently simulated water physical transport and biogeochemical processes in sediments. In hyporheic habitats, Sheibley et al. (2003a, 2003b) developed the same approach to determine kinetic parameters of nitrification and denitrification in a flowing system. These authors elegantly demonstrated the importance of coupled nitrification-denitrification in hyporheic systems where well-oxygenated surface water mixed with lowoxygenated groundwater. However, they only focused on $\mathrm{N}$ cycling and did not consider the influence of $\mathrm{OM}$ on the $\mathrm{NO}_{3}^{-}$and $\mathrm{NH}_{4}^{+}$dynamics. More recently, MermillodBlondin et al. (2008) also presented a model to simulate aerobic respiration in slow filtration columns simulating a hyporheic habitat. Although this previous model has the ability to assess the contribution of interactions between micro-organisms and macro-organisms (tubificid worms) on respiration in sediments, it is restricted to the process of $\mathrm{O}_{2}$ consumption and it did not couple several biogeochemical processes involved in OM processing. In comparison, the present model offers the possibility to simulate processes occurring in sedimentary environments characterized by low $\mathrm{O}_{2}$ availability. By simulating the impact of fine sediment deposition, we clearly showed that sharp reductions of $\mathrm{NO}_{3}^{-}$with depth due to denitrification were only obtained if POC content in fine sediment and/or its potential biodegradation $\left(k_{\mathrm{POC}}\right)$ was/were increased in parallel with a decrease in Darcy velocity. Our simulations are coherent with a recent field experiment (Nogaro et al., 


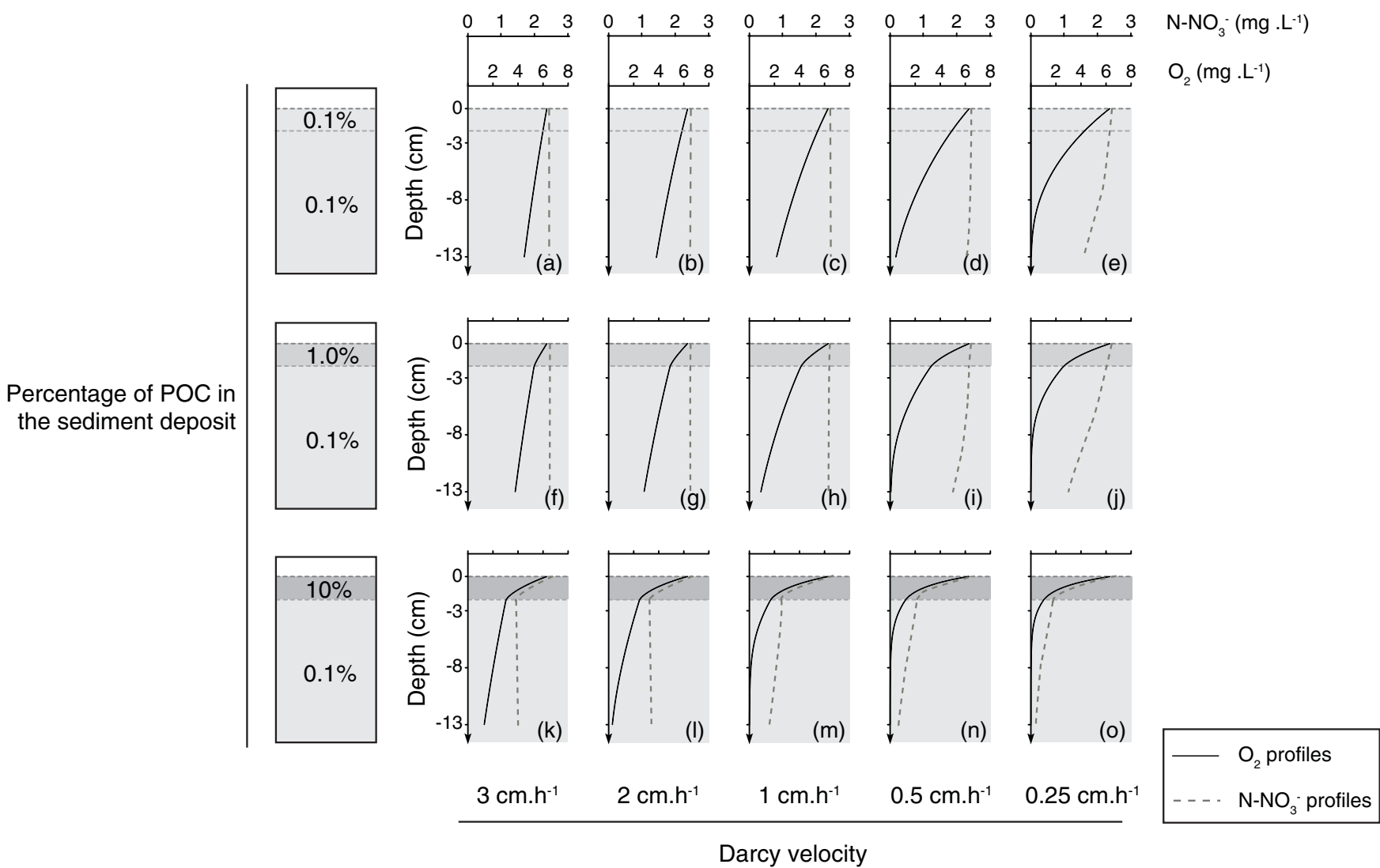

Fig. 4. Vertical profiles of $\mathrm{O}_{2}$ and $\mathrm{N}-\mathrm{NO}_{3}^{-}$simulated for three conditions of POC in the sediment deposit (vertical axis) and five conditions of Darcy velocity (horizontal axis). Other parameters were fixed according to Table 2.

2010) that showed that deposition of fine sediments in streams did not affect $\mathrm{NO}_{3}^{-}$profiles from surface to $\mathrm{HZ}$ when deposited sediments were poorly enriched in OM. Although more experiments are needed to validate our model for conditions of POC enrichment without Darcy velocity change (Fig. 4(k), for $\mathrm{O}_{2}$ and $\mathrm{NO}_{3}^{-}$) and/or decrease in Darcy velocity with low POC contents (Fig. 4(e), for $\mathrm{O}_{2}$ and $\mathrm{NO}_{3}^{-}$), the model has the potential to simulate how excessive sedimentation in streams and river could affect biogeochemical processes and then nutrient cycling and ecosystem metabolism. The application of our model to predict biogeochemical processes in contrasted sedimentary systems, however, needs an assessment of the reactivity of the sedimentary $\mathrm{OM}\left(k_{\mathrm{POC}}\right)$. Indeed, in our experiment, the $k_{\mathrm{POC}}$ used for simulating biogeochemical processes in system impacted by fine sediment deposition was more than 3 -fold higher than the $k_{\mathrm{POC}}$ used for simulation without fine sediment deposition. Therefore, predictions from the model would benefit from a characterization of the $k_{\mathrm{POC}}$ for each type of POC (refractory POC in deep coarse sediments, labile POC in surface fine sediments) present in sediments. According to the literature, the use of stoichiometry (Fischer et al., 2002; Nogaro et al., 2007), protein/carbohydrate contents of the OM (Wilczek et al., 2004), sediment respiration rates (Nedwell et al., 1993; Cokgör et al., 1998) or bioassays associated with the assessment of biodegradation kinetics (Vähätalo

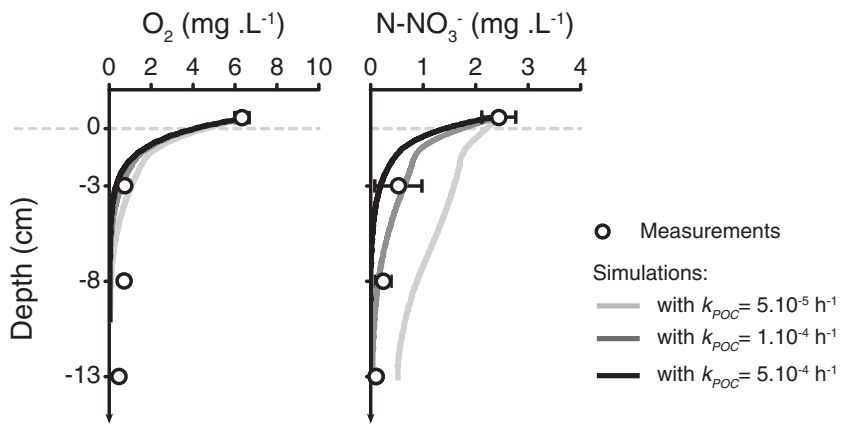

Fig. 5. Measured and simulated vertical profiles of $\mathrm{O}_{2}$ and $\mathrm{N}-$ $\mathrm{NO}_{3}^{-}$obtained in columns with a top layer of fine sand (impacted treatment). Simulated profiles were presented for three values of $k_{\mathrm{POC}}$.

et al., 2010) could be tested as possible methods to obtain a parameterization of the potential biodegradation of sedimentary POC $\left(k_{\mathrm{POC}}\right)$.

\section{Conclusion}

The model presented here can be used as an efficient tool to simulate the response of biogeochemical processes to changes in hydraulic exchanges and/or OM associated 
with deposit sediment in the HZ. Future experiments need to integrate an index of OM biodegradability to better simulate the influence of OM change on biogeochemical processes occurring in sediments. Pending this modification, studies performed in the field or in the laboratory would benefit from the outputs of this kind of model to elaborate hypotheses on the functioning of the watersediment interface. In the case of river sediment functioning, this model can give information about sedimentary processes for different sedimentary features and different trophic conditions influencing the amount of $\mathrm{OM}$ in benthic and HZs. It is therefore conceivable to make predictions about biogeochemical processes occurring in river sediments at different spatial and time scales. On a spatial scale, sediment biogeochemistry in upstream and downstream sections of rivers would strongly differed as up- and downstream sediments often exhibit contrasting hydraulic conductivity and OM characteristics (Vannote et al., 1980; Buffington and Tonina, 2009). On a temporal scale, hydrological events influencing the transport and deposition of sediment and associated OM would also affect river sediment biogeochemistry (Oeurng et al., 2011a, 2011b). Therefore, the mathematical model presented here can be very useful to evaluate biogeochemical functioning in a wide range of environmental conditions.

Acknowledgements. We thank Laurent Simon (UMR 5023 LEHNA, Villeurbanne) for the time spent reviewing an earlier draft of this manuscript and two anonymous reviewers for their very insightful comments. This study was funded by the ANR Biodiversity programme (ANR-06-BDIV-007) InBioProcess 2007-2010.

\section{References}

Beschta R.L. and Jackson W.L., 1979. The intrusion of fine sediments into a stable gravel bed. J. Fish. Res. Board Can., 36, 204-210.

Boulton A.J., Findlay S., Marmonier P., Stanley E.H. and Valett H.M., 1998. The functional significance of the hyporheic zone in streams and rivers. Annu. Rev. Ecol. Syst., 29, 59-81.

Buffington J.M. and Tonina D., 2009. Hyporheic exchange in mountain rivers II: effects of channel morphology on mechanics, scales, and rates of exchange. Geogr. Compass, 3, 1038-1062.

Canavan R.W., Slomp C.P., Jourabchi P., Van Cappellen P., Laverman A.M. and van den Berg G.A., 2006. Organic mineralization in sediment of the coastal freshwater lake and response to salinization. Geochim. Cosmochim. Acta, 70, 2836-2855.

Cokgör E.U., Sözen S., Orhon D. and Henze M., 1998. Respirometric analysis of activated sludge behaviour. I. Assessment of the readily biodegradable substrate. Water Res., 32, 461-475.

Decaux O., 2011. Transport-reactive in porous media applied to the hyporheic zone: evaluation and estimation of parameters from physical and reactive models. Master degree 2nd, Modelling and Biostatistics, University of Toulouse, France, 48 p.
Delmotte S., 2007. Rôle de la bioturbation dans le fonctionnement biogéochimique de l'interface eau-sédiment: Modélisation de la diversité des transports biologiques et effets sur la diagénèse précoce des sédiments d'une retenue. PhD Thesis, Université Toulouse III - Paul Sabatier, 282 p. http://www.mad-environnement.com/pdf/Th\%E8se_ S_Delmotte.pdf

Fiadeiro M.E. and Veronis G., 1977. On weighted-mean schemes for the finite-difference approximation to the advectiondiffusion equation. Tellus, 29, 512-522.

Fischer H., Wanner S.C. and Pusch M., 2002. Bacterial abundance and production in river sediments as related to the biochemical composition of particulate organic matter (POM). Biogeochemistry, 61, 37-55.

Foulquier A., Mermillod-Blondin F., Malard F. and Gibert J., 2011. Response of sediment biofilm to increased dissolved organic carbon supply in groundwater artificially recharged with stormwater. J. Soils Sediments, 11, 382-393.

Gaudet J.P., Jegat H., Vachaud G. and Wierenga P.J., 1977. Solute transfer with exchange between mobile and stagnant water, through unsaturated sand. Soil Sci. Soc. Am. J., 41, 665-671.

Gayraud S. and Philippe M., 2003. Influence of bedsediment features on the interstitial habitat available for macroinvertebrates in 15 French streams. Int. Rev. Hydrobiol., 88, 77-93.

Hancock P.J., 2002. Human impacts on the stream-groundwater exchange zone. Environ. Manage., 29, 763-781.

Lefebvre S., Marmonier P. and Pinay G., 2004. Stream regulation and nitrogen dynamics in sediment interstices: comparison of natural and straightened sectors of a thirdorder stream. River Res. Appl., 20, 499-512.

Mermillod-Blondin F., Gaudet J.-P., Gerino M., Desrosiers G., Jose J. and Creuzé des Châtelliers M., 2004. Relative influence of bioturbation and predation on organic matter processing in river sediments: a microcosm experiment. Freshwater Biol., 49, 895-912.

Mermillod-Blondin F., Mauclaire L. and Montuelle B., 2005. Use of slow filtration columns to assess oxygen respiration, consumption of dissolved organic carbon, nitrogen transformations, and microbial parameters in hyporheic sediments. Water Res., 39, 1687-1698.

Mermillod-Blondin F., Poggiale J.-C., Tolla C., Auger P., Thuiller W. and Creuzé des Châtelliers M., 2008. Using a mathematical model to simulate the influence of tubificid worms (Oligochaeta) on oxygen concentrations in hyporheic sediments. Fundam. Appl. Limnol., 172/2, 135-145.

Middelburg J.J., Vlug T. and van der Nat F.J.W.A., 1993. Organic matter mineralization in marine systems. Glob. Planet. Change, 8, 47-58.

Navel S., Mermillod-Blondin F., Montuelle B., Chauvet E., Simon L. and Marmonier P., 2011. Water-sediment exchanges control microbial processes associated with leaf litter degradation in the hyporheic zone: a microcosm study. Microb. Ecol., 61, 968-979.

Nedwell D.B., Walker T.R., Ellisevans J.C. and Clarke A., 1993. Measurements of seasonal rates and annual budgets of organic carbon fluxes in an Antarctic coastal environment at Signy Island, South Orkney Islands, suggest a broad balance between production and decomposition. Appl. Environ. Microbiol., 59, 3989-3995.

Nogaro G., Mermillod-Blondin F., Montuelle B., Boisson J.-C., Bedell J.-P., Ohannessian A., Volat B. and Gibert J., 2007. 
Influence of a stormwater sediment deposit on microbial and biogeochemical processes in infiltration porous media. Sci. Total Environ., 377, 334-348.

Nogaro G., Datry T., Mermillod-Blondin F., Descloux S. and Montuelle B., 2010. Influence of streambed sediment clogging on microbial processes of the hyporheic zone. Freshwater Biol., 55, 1288-1302.

Oeurng C., Sauvage S. and Sánchez-Pérez J.M., 2011 a. Assessment of hydrology, sediment and particulate organic carbon yield in a large agricultural catchment using SWAT model. J. Hydrol., 401, 145-153.

Oeurng C., Sauvage S., Coynel A., Maneux E., Etcheber H. and Sánchez-Pérez J.-M., 2011b. Fluvial transport of total suspended sediments and organic carbon from a large agricultural catchment during flood events, southwest France. Hydrol. Process., 25, 2365-2378.

Peyrard D., Delmotte S., Sauvage S., Namour P., Gerino M., Vervier P. and Sánchez-Pérez J.M., 2011. Longitudinal transformation of nitrogen and carbon transport and in the hyporheic zone of an N-rich stream: a combined modelling and field study. Phys. Chem. Earth, 36, 599-611.

Ramos J.I., 1986. Numerical solution of reactive-diffusion systems. Part 2: Method of lines and implicit algorithms. Int. J. Comput. Math., 18, 141-161.

Schälchli U., 1992. The clogging of coarse gravel river beds by fine sediment. Hydrobiologia, 235/236, 189-197.

Schoen R., Gaudet J.P. and Elrick D.E., 1999. Modelling of solute transport in a large undisturbed lysimeter, during steady state water flux. J. Hydrol., 215, 82-93.

Servais P., Anzil A. and Ventresque C., 1989. Simple method for determination of biodegradable dissolved organic carbon in water. Appl. Environ. Microbiol., 55, 2732-2734.

Sheibley R.W., Duff J.H., Jackman A.P. and Triska F.J., $2003 \mathrm{a}$. Inorganic nitrogen transformations in the bed of the Shingobee River, Minnesota: integrating hydrologic and biological processes using sediment perfusion cores. Limnol. Oceanogr., 48, 1129-1140.

Sheibley R.W., Jackman A.P., Duff J.H. and Triska F.J., 2003b. Numerical modeling of coupled nitrification-denitrification in sediment perfusion cores from the hyporheic zone of the Shingobee River, MN. Adv. Water Res., 26, 977-987.

US EPA (1991) Methods for Measuring the Acute Toxicity of Effluents and Receiving Waters to Freshwater and Marine Organisms (4th edn,), EPA/600/4-90/027, US Environmental Protection Agency, Washington, pp. 34-35.

Vähätalo A.V., Aarnos H. and Mäntyniemi S., 2010. Biodegradability continuum and biodegradation kinetics of natural organic matter described by the beta distribution. Biogeochemistry, 37, 130-137.

Van Cappellen P., and Wang Y., 2006. Cycling of iron and manganese in surface sediments: a general theory for the coupled transport and reaction of carbon, oxygen, nitrogen, sulfur, iron and manganese. Am. J. Sci., 296, 197-243.

Vannote R.L., Minshall G.W., Cummins K.W., Sedell J.R. and Cushing C.E., 1980. The river continuum concept. Can. J. Fish. Aquat. Sci., 37, 130-137.

Waters T.F., 1995. Sediment in Streams: Sources, Biological Effects and Control, American Fisheries Society, Bethesda, MD, $251 \mathrm{p}$.

Wijsman J.W.M., Herman P.M.J., Middelburg J.J. and Soetaert K., 2002. A model for early diagenetic processes in sediments of the continental shelf of the Black Sea. Estuar. Coast. Shelf Sci., 54, 403-421.

Wilczek S., Fischer H., Brunke M. and Pusch M.T., 2004. Microbial activity within a subaqueous dune in a large lowland river (River Elbe, Germany). Aquat. Microb. Ecol., 36, 83-97.

Wood P.J. and Armitage P.D., 1997. Biological effects of fine sediment in the lotic environment. Environ. Manage., 21, 203-217. 